УДК 612.015:597.22

DOI 10.11603/2311-9624.2020.1.12042

○Ю. Ю. Яров

Донецький національний медичний університет МОЗ України

e-mail: Kaf.stomatologii2@ukr.net

\title{
Динаміка біохімічних та мікробіологічних параметрів при моделюванні різної реактивності організму
}

\section{ІНФОРМАЦІЯ}

Надійшла до редакціï/Received: 10.02.2021 p.

Ключові слова: реактивність організму; спонтанний пародонтит; біохімічні показники; частота виділення та рівень заселення мікрофлори.

\section{АНОТАЦІЯ}

Резюме. Захворювання тканин пародонта за соціально-економічним значенням відносяться до числа найбільш складних проблем у сучасній стоматології. Актуальними залишаються питання уточнення ключових механізмів розвитку і перебігу запально-деструктивного ураження тканин пародонта залежно від стану реактивності організму та можливість управління цими процесами.

Мета дослідження - вивчити динаміку біохімічних та мікробіологічних показників в умовах експерименту з моделюванням крайніх станів гіпер- і гіпореактивності організму.

Матеріали і методи. Досліди виконано на 24 дорослих безпородних собаках масою 8-12 кг зі спотанним пародонтитом. Тварин поділили на три рівні групи, в яких моделювали стани нормо-, гіперта гіпореактивності організму. В сироватці крові й тканинах ясен оцінювали динаміку біохімічних параметрів, а також частоту виділення і рівень заселення мікрофлори дентальної біоплівки при різній реактивності організму.

Результати досліджень та їх обговорення. При гіпер- та гіпореактивності організму відбувається виснаження резервних можливостей антиокисної системи (АОС), про що свідчить достовірне зниження активності основного ферменту антирадикальної ланки АОС - супероксиддисмутази (СОД) - в сироватці крові й біоптаті ясен, відповідно в 1,41 і 2,84 раза $(\mathrm{p}<0,05)$. При цьому вібувається достовірне підвищення активності ферменту фосфоліпази А2 в сироватці крові й тканинах ясен $(\mathrm{p}<0,05)$. Аналіз частоти виділення і рівня заселення мікрофлори дентальної біоплівки у тварин зі спонтанним пародонтитом на тлі порушеної реактивності організму свідчить про збільшення виявлення факультативних та облігатних анаеробів.

Висновки. Моделювання порушеної (гіпер- і гіпо-) реактивності організму призводить до дисбалансу регуляторних систем, що проявляється вираженою деструкцією тканин пародонта та відповідною динамікою біохімічних і мікробіологічних параметрів. Тому перспективним вважаємо подальше вивчення можливості впливу на показники реактивності організму з наближенням їх до значень при нормореакції організму, що забезпечить оптимальний перебіг патологічного процесу в пародонті.
Вступ. Захворювання тканин пародонта за соціально-економічним значенням відносять- ся до числа найбільш актуальних проблем сучасної стоматології. Це пов’язано з їх масо- 
вою поширеністю, значним зростанням деструктруктивних форм вже в молодому віці, високим відсотком рецидивів захворювання, наслідками, що призводять до втрати зубів і порушень функції зубощелепної системи, негативним впливом на організм в цілому [1-6].

Найбільш поширеним і тяжким серед захворювань пародонта $є$ генералізований пародонтит - патологічний процес, що розвивається в тканинах пародонта унаслідок поєднаного впливу різних загальних і місцевих екзо- й ендогенних факторів. При цьому у відповідь на тривалу персистенцію мікрофлори розвивається хронічне запалення, яке являє собою комплекс мікроциркуляторних, гематологічних, імунологічних і сполучнотканинних реакцій на ушкодження. Порушення мікроциркуляції ініціює тканинну гіпоксію, активацію вільнорадикальних процесів, дезорганізацію біомембран із вивільненням біологічно активних речовин (гістамін, серотонін), простагландинів, цитокінів і т. д. Рівень відповідної реакції на ушкодження визначається реактивністю організму: стрес-реакцією, імунологічною реактивністю і т. д. [7-16].

Однак актуальними залишаються питання уточнення ключових механізмів розвитку i перебігу запально-деструктивного ураження тканин пародонта залежно від стану реактивності організму та можливість управління цими процесами.

Метою дослідження було вивчити динаміку біохімічних та мікробіологічних показників в умовах експерименту з моделюванням крайніх станів гіпер- і гіпореактивності організму.

Матеріали і методи. При виконанні експериментальних досліджень враховані рекомендації, викладені в Директиві Європейського Союзу 2010/10/63 щодо експериментів на тваринах, в правилах Міжнародного комітету редакторів медичних журналів, у рекомендаціях Біоетичної експертизи доклінічних та інших наукових досліджень, що виконуються на тваринах (Київ, 2006) і положенні Європейської конвенції про захист хребетних тварин, что використовуються для дослідних та інших наукових цілей (Страсбург, 1986).

Досліди виконано на 24 дорослих безпородних собаках масою 8-12 кг зі спотанним пародонтитом. Тварин поділили на три рівні групи. У першій групі препарати, що порушують реактивність організму, не застосовувалися (нормореактивність організму). При цьому тваринам «плацебо» вводили фізіологічний розчин (ці тварини служили контролем). У другій групі тваринам за схемою вводили імуностимулятор ліпополісахаридної природи - пірогенал. Таким чином моделювали стан гіперреактивності організму. Тварини третьої групи за схемою отримували імунодепресант - «Азатіоприн». Таким чином моделювали стан гіпореактивності організму. Реактивність організму в тварин контролювали визначенням в крові вмісту адренокортикотропного гормону (АКТГ), адреналіну (Ад), кортизолу (Кз), кількості лейкоцитів (Л) й індексу зсуву лейкоцитів крові (ІЗЛК) на 1-шу, 4-ту, 7-му, 15-ту добу [17]. За допомогою наборів радіоімунним методом визначали АКТГ (фірма «Oris», Франція), кортизол (Інститут біоорганічної хімії АН Білорусі), адреналін методом роздільного дослідження адсорбції на окису алюмінію з реєстрацією на флуориметрі «Біан 130». Кількість лейкоцитів крові й ІЗЛК визначали лабораторним методом. Кінетика ІЗЛК відображає зміни, що відбуваються в пулі лейкоцитів крові, зумовлені їх участю у формуванні запального інфільтрату. Забір венозної крові проводили в ранкові години натще (ввечері напередодні дослідження тварин не годували) з ліктьової вени в обсязі 10 мл.

У сироватці крові й тканинах ясен (отримували під місцевою анастезією) тварин зі спонтанним пародонтитом оцінювали динаміку біохімічних параметрів, а також частоту виділення і рівень заселення мікрофлори дентальної біоплівки при різній реактивності організму. Біохімічним методом у сироватці крові й в надосадовій рідині гомогенатів тканин ясен визначали вміст малонового діальдегіду (МДА) і активність супероксиддисмутази (СОД), активність фосфоліпази $\mathrm{A}_{2}$ за методом Ханакана. Принцип методу визначення МДА полягає в наступному - при нагріванні в кислому середовищі частина продуктів ПОЛ, яка належить до класу ендоперекисів, розщеплюється, синтезуючи МДА, взаємодія якого з тіобарбітуровою кислотою (ТБК) призводить до утворення пофарбованого в рожевий колір комплексу. Екстинцію реєстрували при довжинах хвиль 532 і 590 нм для виключення поглинання забарвлених комплексів ТБК речовинами неліпідної природи. Активність Сод визначали шляхом вивчення ії̈ здатності гальмувати аутоокислення адреналіну при pH 10,2. Мікробіологічні дослідження включали виділення і видову ідентифікацію мі- 
кроорганізмів дентальної біоплівки з використанням техніки аеробного й анаеробного культивування шляхом посівів клінічного матеріалу з транспортного тампона на спеціальні живильні середовища вітчизняного виробництва і фірми bioMerieux, Франція. Для культивування використовували наступний набір поживних середовищ:

- для аеробних і факультативних бактерій - кров'яний агар, середовище Чистовича, агар Сабуро, шоколадний агар з ПоліВітеКсом (bioMerieux);

- для анаеробних бактерій - агар Шедлера (bioMerieux) + $5 \%$ еритроцитів барана, агар Шедлера + 5 \% еритроцитів барана + ванкоміцин + неоміцин (для виключення контамінованої мікрофлори), агар - тріптіказа - соєве, агар Мюллера-Хінтона, середовище САР (для капноцитофагів).

Культивування матеріалу на поживних середовищах здійснювали в термостаті при температурі 37 градусів C 3-5 діб. Чашки 3 анаеробними культурами попередньо поміщали в мікроанаеростати bioMerieux, а потім у термостат. Ідентифікацію виділених чистих культур проводили за морфолого-культуральними та біохімічними ознаками відповідно до загальноприйнятих методик, а також за допомогою ідентифікаційних тест-смужок АРI bioMerieux: API Staph., API 20 Strep., API 20 E, API 20 А. Результати кількісного дослідження мікрофлори - рівня заселення - висловлюва- ли в колонієутворюючих одиницях на 1 мл (КУО/Мл).

Забір дентальної біоплівки проводили 3 пришийкової поверхні верхніх великих та малих ікол за допомогою стерильних кюрет 3 наступним швидким нанесенням на стандартний стерильний тампон транспортної системи фірми «Sarstedt» (Німеччина), що дозволяє збільшити терміни транспортування в бактеріологічну лабораторію до 72 год.

Статистичну обробку отриманих цифрових даних здіснювали за допомогою комп'ютерної програми Statistica 8.0 (STA862D175437Q). Для кожної вибіркової сукупності спостережень (n) обчислювали середнє арифметичне значення (M), стандартну помилку середнього значення (SE), стандартне відхилення (SD), $95 \%$ довірчий інтервал справжнього середнього значення, використовуючи t-критерій Стьюдента. Розраховували рівень значущості відмінностей середніх значень показника в незалежних вибірках (р) за функцією розподілу t-критерію Стьюдента: при p <0,05 - різниця значима; при р>0,05 - відмінність незначима.

Результати досліджень та їх обговорення. Реактивність організму в тварин контролювали визначенням в крові вмісту адренокортикотропного гормону (АКТГ), адреналіну (Ад), кортизолу (Кз), кількості лейкоцитів (Л) i індексу зсуву лейкоцитів крові (ІЗЛК) (табл. 1). Як видно з даної таблиці, в першій групі (нормореактівность організму) на 1-шу добу

таблиия 1. Вміст адренокортикотропного гормону, адреналіну, кортизолу, кількості лейкоцитів й індексу зсуву лейкоцитів крові в плазмі крові тварин із спонтанним пародонтитом при нормо- (1), гіпер- (2) і гіпореактивності (3) організму $(\mathrm{M} \pm \mathrm{SE})$

\begin{tabular}{|c|c|c|c|c|c|c|}
\hline \multirow{2}{*}{$\begin{array}{c}\text { Показ- } \\
\text { ник }\end{array}$} & \multirow{2}{*}{$\begin{array}{c}\text { Контрольне } \\
\text { значення }\end{array}$} & \multirow{2}{*}{$\begin{array}{c}\text { Група } \\
\text { дослідження }\end{array}$} & \multicolumn{4}{|c|}{ Термін спостереження (доба) } \\
\hline & & & 1-ша & 4-та & 7-ма & 15-та \\
\hline $\begin{array}{l}\text { АКТГ, } \\
\text { пГ/МЛ }\end{array}$ & $77,66 \pm 9,9$ & $\begin{array}{l}1 \\
2 \\
3\end{array}$ & $\begin{array}{c}148,4 \pm 8,8 * \\
206,8 \pm 12,6 * \\
122,2 \pm 8,1 *\end{array}$ & $\begin{array}{c}140,7 \pm 7,9 * \\
116,2 \pm 11,2 * \\
163,2 \pm 9,9 *\end{array}$ & $\begin{array}{l}96,3 \pm 8,7 \\
93,2 \pm 9,3 \\
81,9 \pm 7,4\end{array}$ & $\begin{array}{c}76,2 \pm 8,4 \\
102,3 \pm 8,9 \\
80,4 \pm 7,6\end{array}$ \\
\hline $\begin{array}{l}\text { Ад, } \\
\text { мкг/л }\end{array}$ & $0,47 \pm 0,07$ & $\begin{array}{l}1 \\
2 \\
3\end{array}$ & $\begin{array}{l}1,37 \pm 0,09 * \\
1,99 \pm 0,24 * \\
0,85 \pm 0,12 *\end{array}$ & $\begin{array}{c}0,47 \pm 0,03 \\
1,34 \pm 0,20 * \\
0,64 \pm 0,12\end{array}$ & $\begin{array}{c}0,52 \pm 0,04 \\
1,82 \pm 0,22 * \\
0,38 \pm 0,03\end{array}$ & $\begin{array}{l}0,47 \pm 0,07 \\
0,78 \pm 0,28 \\
0,43 \pm 0,06\end{array}$ \\
\hline Кз, нмоль/Л & $182 \pm 7$ & $\begin{array}{l}1 \\
2 \\
3\end{array}$ & $\begin{array}{l}347 \pm 32 * \\
496 \pm 37 * \\
309 \pm 30 *\end{array}$ & $\begin{array}{l}212 \pm 11 \\
81 \pm 23 * \\
109 \pm 6 *\end{array}$ & $\begin{array}{c}153 \pm 8 \\
94 \pm 12 * \\
62 \pm 7 *\end{array}$ & $\begin{array}{c}154 \pm 7 \\
102 \pm 12 * \\
74 \pm 4 *\end{array}$ \\
\hline $\begin{array}{l}\text { Л, } \\
\text { Е/л білка }\end{array}$ & $5,6 \pm 0,5$ & $\begin{array}{l}1 \\
2 \\
3\end{array}$ & $\begin{array}{c}9,7 \pm 0,9 * \\
12,9 \pm 1,4 * \\
7,1 \pm 0,8\end{array}$ & $\begin{array}{c}7,7 \pm 0,8 * \\
10,3 \pm 1,0 * \\
7,9 \pm 0,8 *\end{array}$ & $\begin{array}{c}7,1 \pm 0,8 \\
9,2 \pm 0,8 * \\
7,8 \pm 1,0 *\end{array}$ & $\begin{array}{l}6,0 \pm 0,5 \\
8,0 \pm 0,8 \\
5,8 \pm 0,6\end{array}$ \\
\hline $\begin{array}{l}\text { ІЗЛК, } \\
\text { безрозм. }\end{array}$ & $0,82 \pm 0,08$ & $\begin{array}{l}1 \\
2 \\
3\end{array}$ & $\begin{array}{c}1,47 \pm 0,16 * \\
1,95 \pm 0,22 * \\
0,94 \pm 0,16\end{array}$ & $\begin{array}{l}1,37 \pm 0,12 * \\
1,76 \pm 0,09 * \\
1,14 \pm 0,08 *\end{array}$ & $\begin{array}{c}1,16 \pm 0,11 \\
1,62 \pm 0,14 * \\
0,96 \pm 0,08\end{array}$ & $\begin{array}{l}0,94 \pm 0,10 \\
1,12 \pm 0,14 \\
1,13 \pm 0,16\end{array}$ \\
\hline
\end{tabular}

Примітка. * - р<0,05 проти контрольних значень. 
експерименту спостерігався достовірний підйом концентрації АКТГ, АД, Кз, Л і ІЗЛК з подальшим зниженням. Серед досліджуваних параметрів звертає увагу більш висока лабільність зміни вмісту адреналіну і кортизолу. Зниження їх рівня після початкового підйому відбулося вже на 4-ту добу. Нормалізація АКТГ, Л і ІЗЛК була повільнішою, досягаючи контрольних значень на 15-ту добу. Описана вище картина відповідає стану нормореактивності організму. В другій групі (моделювання гіперреактивності організму) на 1-шу добу всі досліджувані показники досягали більш ви- соких значень з подальшою сповільненою інволюцією адренокортикотропного гормону і різким падінням кортизолу, порівняно з першою групою, що підтверджує модель гіперреакції. У третій групі на 1-шу добу рівні АКТГ, Кз, кількість Л і ІЗЛК були нижчими з подальшою сповільненою інволюцією порівняно 3 першою і другою групами, що підтверджувало модель гіпореакції.

Результати динаміки біохімічних параметрів у сироватці крові й тканинах ясен тварин представлені в таблиці 2.

Таблищя 2. Біохімічні показники в сироватці крові й тканинах ясен тварин на 28-ту добу моделювання

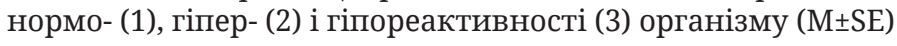

\begin{tabular}{|c|c|c|c|c|c|}
\hline $\begin{array}{c}\text { Об’єкт } \\
\text { дослідження }\end{array}$ & Показник & $\begin{array}{c}\text { Контрольне } \\
\text { значення }\end{array}$ & $\begin{array}{l}\text { Нормо- } \\
\text { реакція }\end{array}$ & $\begin{array}{c}\text { Гіпер- } \\
\text { реакція }\end{array}$ & $\begin{array}{c}\text { Гіпо- } \\
\text { реакція }\end{array}$ \\
\hline \multirow[t]{3}{*}{$\begin{array}{l}\text { Сироватка } \\
\text { крові }\end{array}$} & $\begin{array}{l}\text { МДА, } \\
\text { мКмоль/л }\end{array}$ & $6,26 \pm 0,16$ & $6,52 \pm 0,35$ & $10,78 \pm 0,46 *$ & $9,32 \pm 0,19 *$ \\
\hline & $\begin{array}{l}\text { СОД, од. } \\
\text { активності }\end{array}$ & $0,372 \pm 0,016$ & $0,394 \pm 0,017$ & $0,264 \pm 0,015 *$ & $0,242 \pm 0,014^{*}$ \\
\hline & $\begin{array}{l}\text { ФЛА2, } \\
\text { нКат/Л }\end{array}$ & $0,18 \pm 0,01$ & $0,20 \pm 0,01$ & $0,49 \pm 0,02 *$ & $0,31 \pm 0,01 *$ \\
\hline \multirow[t]{3}{*}{$\begin{array}{l}\text { Тканини } \\
\text { ясен }\end{array}$} & $\begin{array}{l}\text { МДА, } \\
\text { МКмоль/Кг }\end{array}$ & $24,0 \pm 2,2$ & $25,2 \pm 2,9$ & $45,9 \pm 3,8 *$ & $39,8 \pm 2,3 *$ \\
\hline & $\begin{array}{l}\text { СОД, од. актив- } \\
\text { ності }\end{array}$ & $0,448 \pm 0,018$ & $0,464 \pm 0019$ & $0,158 \pm 0,016 *$ & $0,140 \pm 0,014 *$ \\
\hline & $\begin{array}{l}\text { ФЛА2, } \\
\text { мккат/г }\end{array}$ & $10,18 \pm 0,84$ & $12,23 \pm 0,92$ & $20,98 \pm 1,08 *$ & $19,35 \pm 0,99 *$ \\
\hline
\end{tabular}

Примітка. * - p<0,05 проти контрольних значень.

Пусковим механізмом прогресуючої деструкції альвеолярної кістки при гіперреактивності організму є інтенсифікація ПОЛ у тканинах, що підтверджується достовірним збільшенням вмісту малонового діальдегіду (МДА) - кінцевого продукту ПОЛ - в сироватці крові й в біоптатах ясен, відповідно в 1,72 і 1,91 раза $(\mathrm{p}<0,05)$. У міру розвитку деструктивно-запального процесу в пародонті з інтенсифікацією вільнорадикального окиснення ліпідів відбувається виснаження резервних можливостей антиокисної системи (АОС), про що свідчить достовірне зниження активності основного ферменту антирадикальної ланки АОС - супероксиддисмутази (СОД) - в сироватці крові й біоптаті ясен, відповідно в 1,41 і 2,84 раза $(\mathrm{p}<0,05)$. Механізм прогресуючого ураження структур пародонта у тварин зі спонтанним пародонтитом при гіпореактивності організму пов'язаний із посиленням вільнорадикальних процесів на тлі недостатньої активності антиоксидантної системи (АОС), що проявляється достовірним зниженням СОД і зростанням МДА в сироватці крові (відповідно в 1,53 і 1,48 раза, p<0,05) і біоптатах ясен (відповідно в 3,20 і 1,65 раза, $\mathrm{p}<0,05)$.

Проведені експериментальні дослідження показали також, що зміна реактивності організму в тварин зі спонтанним пародонтитом супроводжується достовірним підвищенням активності ферменту фосфоліпази $\mathrm{A}_{2}$ в сироватці крові й тканинах ясен. Під впливом даного ферменту з мембранних фосфоліпідів утворюється арахідонова кислота, яка є джерелом потужних за метаболічним і фізіологічним ефектами речовин - простагландинів і лейкотрієнів. Вивчення активності ФЛА2 показало, що на тлі моделювання гіперреактивності організму даний показник зростає більшою мірою в сироватці крові порівняно 3 таким в біоптатах ясен, відповідно в 2,72 і 2,06 раза $(\mathrm{p}<0,05)$. Цей факт можна пояснити тим, що при розвитку синдрому пероксидації високореактивні вільні радикали мають ши- 
рокий діапазон біологічної дії, вони не тільки руйнують біомембрани, а й активізують ферментативний гідроліз, що відбивається на біохімічних показниках у сироватці крові. На тлі гіпореактивності організму більш значущим було підвищення активності ферменту в тканинах ясен порівняно з таким у сироватці крові, відповідно в 1,72 і 1,90 раза (p<0,05). При цьому більш висока активність ФЛА2 в біоптатах ясен пояснюється зростанням активності внутрішньоклітинної (тканинної) форми ферменту, так як кількість клітин у вогнищі запалення пародонта значно вище, ніж в судинному руслі.

Результати визначення частоти виділення і рівня заселення мікрофлори дентальної біоплівки при спонтанному пародонтиті на тлі різної реактивності організму показали, що в дентальній біоплівці у тварин контрольної групи і при нормореактивності організму відзначені схожі мікробіологічні параметри. При цьому встановлено, що найбільш часто зустрічаються аеробні факультативні грампозитивні бактерії роду Streptococcus i Staphylococcus, в середньому відповідно в 58 i 62 \% випадків. Їх спектр представлений наступними видами: Str.mitis, Str.mutans, Str. intermedius, S. haemolyticus, S. hominis. В поодиноких випадках зустрічалися S. auricularis, S. warneri, S. aureus i S. schleiferi. Необхідно зазначити, що такі види Streptococcus i Staphylococcus, як Str. pyogenes, Str. faecium, Str.equinus, S. cohnii, S. simulans, S. lentus y тваринах не виявлено. При оцінці рівня заселення дентальної біоплівки аеробними коками встановлено, що кількість КУо бактерій в 1 мл клінічного матеріалу в середньому становить $10^{6}$. Факультативні грамнегативні палички роду Escherichia coli i Enterobacter зустрічаються в середньому відповідно в 33 i 7 \% випадків. При цьому такі представники даної групи паличок, як Klebsiella, Citrobacter i Capnocytophaga, в дентальній біоплівці не виявлені. У 10 \% випадків у тварин цих груп виділені бактерії роду Peptostreptococcus (видів P. anaerobius, P. prevotii) і роду Porphyromonas (вид Р. gingivalis), в $13 \%$ випадків - бактерії роду Prevotella (вид P. oralis). Крім того, у $37 \%$ випадках виявлені грамнегативні анаеробні бактерії роду Fusobacterium (види F. Nucleatum i F. necrophorum). Середня кількість КУО цих анаеробів в 1 мл клінічного матеріалу становить $10^{5}-10^{7}$. Анаеробних бактерій роду Actinomyces i Bacteroidas, а також аеробних роду Pseudomonas не виявлено. Таким чином, аналіз частоти виділення і рівня заселення мікрофлори дентальної біоплівки у тварин контрольної групи і при нормореактивності організму свідчить про наявність переважно аеробно-анаеробних асоціацій.

Результати вивчення частоти виділення і рівня заселення мікрофлори дентальної біоплівки у тварин зі спонтанним пародонтитом при гіпер- і гіпореактивності організму вказують на їх схожість між собою і ряд відмінностей від таких параметрів у тварин контрольної групи і при нормореакції. У дентальній біоплівці в тварин аеробні факультативні грампозитивні бактерії роду Streptococcus i Staphylococcus зустрічалися в середньому відповідно, в 50 і 37 \% випадків, що значно рідше порівняно 3 контролем. При цьому особливо значними були відміності частоти виділення бактерій роду Streptococcus. Значною мірою порівняно 3 контролем і тваринами 3 нормореакцією був звужений спектр виявлених аеробів. Так, кількість видів стрептококів зменшилася на 3 види: Str.mitis, Str.mutans, Str. intermedius. Оцінка рівня заселення дентальної біоплівки стрептококами показала, що такий був схожим з контрольними значеннями - кількість КУО бактерій в 1 мл клінічного матеріалу в середньому становить $10^{6}$. При цьому рівень заселення стафілококами в середньому досягав $10^{5}$, що в 10 разів менше порівняно 3 таким у контрольній групі й у тварин із нормореакцією. Крім аеробних коків у дентальній біоплівці тварин зі зміненою реактивністю організму відзначена поява аеробних грамнегативних паличок роду Pseudomonas. Необхідно зазначити, що в дентальній біоплівці також розширився спектр, збільшилася частота виявлення й рівень заселення факультативних грамнегативних паличок. Так, з'явилися представники родів Klebsiella i Capnocytophaga. Крім того, збільшилася кількість випадків виділення з дентальної біоплівки палички роду Escherichia coli i Enterobacter. Звертає увагу розширення спектра, збільшення частоти виділення і рівня заселення дентальної біоплівки грампозитивними і грамнегативними анаеробами. Так, в поодиноких випадках були виявлені анаеробні бактерії родів Actinomyces i Bacteroidas; збільшилася частота виділення Peptostreptococcus, Porphyromonas, Prevotella i Fusobacterium. При цьому рівень заселення дентальної біоплівки Peptostreptococcus, Porphyromonas i Fusobacterium збільшився в 
5-10 разів. Аналіз частоти виділення і рівня заселення мікрофлори дентальної біоплівки у тварин зі спонтанним пародонтитом на тлі порушеної реактивності організму свідчить про переважання аеробно-анаеробних асоціацій зі збільшенням виявлення факультативних та облігатних анаеробів.

Висновки. Виявлена динаміка біохімічних та мікробіологічних показників при нормореактивності організму визначає адекватні та узгоджені за часом і рівнем зміни регуляторних систем, що забезпечує адаптацію до існуючого запально-деструктивного процесу в пародонті. Моделювання порушеної (гіпер- i гіпо-) реактивності організму призводить до дисбалансу регуляторних систем і розвитку дезадаптаційного сидрому, що проявляється вираженою деструкцією тканин пародонта та відповідною динамікою біохімічних і мікробіологічних параметрів.

Перспективним вважаємо подальше вивчення можливості впливу на показники реактивності організму з наближенням їх до значень при нормореакції організму, що забезпечить оптимальний перебіг патологічного процесу в пародонті.

\section{(СЮ. Ю. Яров}

Донецкий национальный медицинский университет МО3 Украины

\section{Динамика биохимических и микробиологических параметров при моделировании различной реактивности организма}

Резюме. Заболевания тканей пародонта по социально-экономическому значению относятся к числу
наиболее сложных проблем современной стоматологии. Актуальними остаются вопросы уточнения
ключевых механизмов развития и течения воспалительно-деструктивного поражения тканей паро-
донта в зависимости от состояния реактивности организма и возможность управления этими про-
цессами.

Цель исследования - изучить динамику биохимических и микробиологических показателей в условиях эксперимента с моделированием пограничных состояний гипер- и гипореактивности организма.

Материалы и методы. Исследования выполнены на 24 взрослых беспородных собаках массой 8-12 кг со спотанным пародонтитом. Животные были разделены на три равные группы, в которых моделировали состояния нормо-, гипер- и гипореактивности организма. В сыроватке крови и тканях десны оценивали динамику биохимических параметров, а также частоту виделения и уровень заселения микрофлоры дентальной биопленки при различной реактивности организма.

Результаты исследований и их обсуждение. При гипер- и гипореактивности организма происходит истощение резервных возможностей антиокислительной системы (АОС), о чем свидетельствует достоверное снижение активности основного фермента антирадикального звена АОС супероксиддисмутазы (СОД) - в сироватке крови и биоптате десны, соответственно, в 1,41 и 2,84 раза $(\mathrm{p}<0,05)$. При этом происходит достоверное повышение активности фермента фосфолипазы А2 в сироватке крови и тканях десны ( $<0,05)$. Анализ частоты виделения и уровня заселения микрофлоры дентальной биопленки у животных со спонтанным пародонтитом на фоне нарушеной реактивности организма свидетельствует о преобладании аэробно-анаэробных ассоциаций с увелечением выявления факультативных и облигатных анаэробов.

Выводы. Моделирование нарушенной (гипер- и гипо-) реактивности организма приводит к дисбалансу регуляторных систем, что проявляется выраженной деструкцией тканей пародонта и соответствующей динамикой биохимических и микробиологических параметров. Поэтому перспективным считаем дальнейшее изучение возможности влияния на показатели реактивности организма с приближением их к значениям при нормореакции организма, что обеспечит оптимальное течение патологического процесса в пародонте.

Ключевые слова: реактивность организма; спонтанный пародонтит; биохимические показатели; частота виделения и уровень заселения микрофлоры. 


\section{Dynamics of biochemical and microbiological parameters in modelling different reactivity of the organism}

Summary. Periodontal diseases in socio-economic importance are among the most difficult problems of modern dentistry. The issues of clarifying the key mechanisms of development and nature of inflammatory and destructive lesions of periodontal tissues depending on the condition of reactivity of the organism and the ability to control these processes remain relevant.

The aim of the research was to study the dynamics of biochemical and microbiological parameters in the experiment with modelling the extreme conditionss of hyper- and hyporeactivity of the organism.

Materials and methods. The experiments were performed on 24 adult not purebred dogs weighing 8-12 kg with spontanious periodontitis. Animals were divided into three levels of groups, where the states of normo-, hyper- and hyporeactivity of the organism were stimulated. In the blood serum and gum tissues the dynamics of biochemical parameters was assessed, as well as the frequency of secretion and the level of microflora population of the dental biofilm in cases of different reactivity of the organism.

Research results and their discussion. When the body is hyper- and hyporeactive, the reserve capacity of the antioxidant system (AOC) is depleted, as evidenced by a significant decrease in the activity of the main enzyme of the anti-radical link of AOC - superoxide dismutase (SOD) - in serum and gum biopsy, respectively, 1.41 and 2.84 times more $(p<0.05)$. It causes a significant increase in the activity of the enzyme phospholipase A2 in serum and gum tissue ( $<0.05)$. The analysis of the frequency of secretion and the level of microflora population of dental biofilm in animals with spontaneous periodontitis against impaired reactivity of the organism indicates the predominance of aerobic-anaerobic associations with increasing detection of facultative and obligate anaerobes.

Conclusions. Modelling of impaired (hyper- and hypo-) reactivity of the organism provokes the imbalance of regulatory systems, which is manifested by the apparent destruction of periodontal tissues and the corresponding dynamics of biochemical and microbiological parameters. Therefore, we consider further studying of the possibility of influencing the reactivity of the organism with their approximation to the values of the body's normoreaction promosing, which will provide the optimal development of the pathological process in the periodontium.

Key words: organism reactivity; spontaneous periodontitis; biochemical parameters; frequency of excretion and level of microflora population.

\section{СПИСОК ЛІТЕРАТУРИ}

1. Борисенко А. В. Обгрунтування вибору засобів індивідуальної гігієни порожнини рота при лікуванні уражень маргінального пародонту / А. В. Борисенко, К. О. Мялківський // Современная стоматология. - 2015. - № 2. - С. 24-27.

2. Заболотний Т. Д. Запальні захворювання пародонта / Т. Д. Заболотний, Т. І. Пупін, А. В. Борисенко. - Львів : ГалДент, 2013. - 206 с.

3. Петрушанко Т. О. Інтегральний індивідуальний підхід у профілактиці захворювань пародонта : автореф. дис. на здобуття наукового ступеня д-ра мед. наук : 14.01.22 / Т. О. Петрушанко ; Націон. мед ун-т ім. О. О. Богомольця. - К., 2001. - 39 с.

4. Relationship between psychological factors and oral health status and behaviours / A. Alkan, O. Cakmak, S. Yilmaz [et al.] // Oral Health Prev. Dent. - 2015. Vol. 13 (4). - P. 331-339.

5. Jenkins W. M. Epidemiology of periodontal diseases in children and adolescents / W. M. Jenkins, P. N. Papapanou // Periodontology 2000. - 2001. Vol. 26. - P. 16-32.

6. Slots J. Periodontitis: facts, fallacies and the future / Slots J. // Periodontology. - 2017. - Vol. 1 (75). - P. 7-23.
7. Состояние тканей пародонта у пациентов, находящихся на лечении в многопрофильном стационаpe / В. М. Гринин, В. Д. Вагнер, Д. С. Кабак [та ін.] // Институт стоматологии. - 2019. - № 3. - С. 31-34.

8. Кононова О. В. Віддалені результати лікування хворих на генералізований пародонтит з проявами психоемоційного стресу / О. В. Кононова // Новини стоматології. - 2019. - № 2 (99). - С. 6-10.

9. Петрушанко Т. О. Стрес-індуковані зміни мікробіому ясенної борозни від гендерного фактору / Т. О. Петрушанко, В. В. Череда, Г. А. Лобань // Вiсник проблем біології і медицини. - 2017. - Вип. 4, т. 1 (139). - С. 240-242.

10. Анализ факторов риска воспалительных заболеваний пародонта / А. Ч. Пашаев, В. М. Гасанов, С. Т. Гусейнова [и др.] // Сучасна стоматологія. 2020. - № 1. - С. 39-41.

11. Самойленко А. В. Сучасні аспекти етіології, патогенезу та лікування різних клінічних варіантів генералізованного пародонтиту : автореф. дис. на здобуття наукового ступеня д-ра мед. наук : 14.01.22 / А. В. Самойленко ; Ін-т стомат. АМН України. - Одеca, 2003. -34 c. 
12. Силенко Ю. І. Клініко-патогенетичне обгрунтування лікування генералізованого пародонтиту 3 використанням низькомолекулярних поліпептидних препаратів : автореф. дис. на здобуття наукового ступеня д-ра мед. наук : 14.01.22 / Ю. І. Силенко ; Укр. мед. стом. акад. - Полтава, 2000. - 42 с.

13. Мельничук Г. М. Цитокиновый профиль слюны у больных генерализованым пародонтитом / Г. М. Мельничук // Современная стоматология. 2013. - № 1. - С. 35-40.

14. Поширеність та інтенсивність захворювань тканин пародонта в осіб молодого віку на тлі первинного гіпотиреозу / О. М. Репецька, М. М. Рожко, Н. В. Скрипник, О. М. Ільницька // Сучасна стоматологія. - 2020. - № 1. - С. 46-48.

\section{REFERENCES}

1. Borysenko, A.V., \& Mialkivkyi, C.O. (2015). Obgruntuvannia vyboru zasobiv indyvidualnoi hihiieny porozhnyny rota pry likuvanni urazhen marhinalnoho parodontu [Rationale for the choice of personal hygiene in the treatment of marginal periodontal lesions]. Sovremennaya stomatologiya - Modern Dentistry, 2, 2427 [in Ukrainian].

2. Zabolotnyi, T.D., Pupin, T.I., \& Borisenko, A.V. (2013). Zapalni zahvoriuvannia parodonta [Inflammatory diseases of the periodontium]. Lviv: GalDent [in Ukrainian].

3. Petrushanko, T.O. (2001). Intehralnyi indyvidualnyi pidhid $\mathrm{u}$ profilaktytsi zakhvoriuvan parodonta [An integrated individual approach in the prevention of periodontal disease]. Doctor's thesis. Kiev [in Ukrainian]. 4. Alkan, A., Cakmak, O., Yilmaz, S., Cebi, T., \& Gurgan C. (2015). Relationship between psychological factors and oral health status and behaviours. Oral Health Prev. Dent, 13 (4), 331-339. DOI: 10.3290/j.ohpd.a32679

5. Jenkins, W.M., \& Papapanou, P.N. (2000). Epidemiology of periodontal diseases in children and adolescents. Periodontology, 26, 16-32.

6. Slots, J. (2017). Periodontitis: facts, fallacies and the future. Periodontology, 1 (75), 7-23. DOI: 10.1111/ prd.12221

7. Grinin, V.M., Vagner, V.D., Cabak, D.S., Epifanov, S.A., \& Jivotov, V.A. (2019). Sostoyanie tkanei parodonta $\mathrm{u}$ patsiyentov, nakhodyaschihsya na lechenii $\mathrm{v}$ mnogoprofilnom statsionare [The condition of periodontaltissues for patients undergoing treatment in a multidisciplinary hospital]. Institut stomatologii Institute of Dentistry, 3, 31-34 [in Russian].

8. Cononova, O.V. (2019). Viddaleni rezultaty likuvannia khvorykh na heneralizovanyi parodontyt z proiavamy psikhoemotsiinoho stresu [Long-term results of treatment of patients with generalized periodontitis with manifestations of psychoemotional stress]. Novyny stomatolohii - Dentistry News, 2 (99), 6-10 [in Ukrainian]. 9. Petrushanko, T.O., Vhereda, G.A., \& Loban, V.V. (2017). Stres-indukovani zminy mikrobiomu yasennoi borozny vid gendernoho faktoru [Stress-induced changes in the microbiome of the gingival sulcus from the gender factor]. Visnyk problem biolohii i medytsyny - Bulletin of Problems of Biology and Medicine, 1 (139), 240-242 [in Ukrainian].
15. Марковська I. В. Динаміка стоматологічного статусу пацієнтів, які піддаються впливу неіонізуючого низькочастотного електромагнітного випромінювання промислової частоти (70 кГц) / I. В. Марковська, I. I. Соколова // East Scientific Journal. - 2019. - № 9 (2). - P. 16-19.

16. Ультраструктурна організація тканин ясен хворих на генералізований пародонтит при кардіоваскулярній патологія / О.В.Копчак, Г. Ф. Білоклицька, Л. О. Стеченко, О. І. Кривошеєва // Світ медицини та біології. - 2017. - № 1 (59). - С. 121-126.

17. Сокрут В. Н. Формы реактивности организма и заживление инфаркта миокарда: дис. ... д-ра мед. наук. 14.00.16 / В. Н. Сокрут ; Донецкий гос. мед. ин-т. - Донецк, 1992. - 467 с.

10. Pashaev, A.Ch., Gasanov, V.M., \& Guseinova, S.T. (2020). Analiz faktorov riska vospalitelnyh zabolevaniy parodonta [Analysis of risk factors for inflammatory periodontal diseases]. Sovremennaya stomatologiya Modern Dentistry, 1, 39-41 [in Russian].

11. Samoilenko, A.V. (2003). Suchasni aspekty etiolohii, patohenezu ta likuvannia riznykh klinichnykh variantiv heneralizovannoho parodontytu [Modern aspects of etiology, pathogenesis and treatment of different clinical variants of generalized periodontitis] Doctor's thesis. Odessa [in Ukrainian].

12. Silenko, Y.I. (2000). Kliniko-patohenetychne obgruntuvannia likuvannia heneralizovanoho parodontytu z vykorystanniam nyzkomolekulyarnykh polipeptydnykh preparativ [Clinical and pathogenetic substantiation of treatment of generalized periodontitis using low molecular weight polypeptide drugs] Doctor's thesis. Poltava [in Ukrainian].

13. Melnichuk, G.M. (2013). Tsytokinovyi profil sliuny $\mathrm{u}$ bolnyh generalizovanym parodontitom [Cytokine profile of saliva in patients with generalized periodontitis]. Sovremennaya stomatologiya - Modern Dentistry, 1, 35-40 [in Russian].

14. Repetska, O.M., Rozhko, M.M., Skrypnyk, N.V., \& Ilnytska, O.M. (2020). Poshyrenist ta intensyvnist zakhvoriuvan tkanyn parodonta $\mathrm{v}$ osib molodoho viku na tli pervynnoho hipotyreozu [Prevalence and intensity of periodontal diseases in young people on the background of primary hypothyroidism]. Suchasna stomatologiya - Modern Dentistry, 1, 42-48 [in Ukrainian].

15. Markovska, I.V., \& Sokolova, I.I. (2019). Dinamika stomatolohichnoho statusu patsiientiv, yaki piddaiutsia vplyvu neionizuiuchoho nyzkochastotnoho elektromahnitnoho vyprominiuvannia promyslovoi chastoty $(70 \mathrm{kHts})$ [Dynamics of the dental status of patients exposed to non-ionizing low-frequency electromagnetic radiation of industrial frequency (70 kHz)]. East Scientific Journal, 9 (2), 16-19 [in Ukranian]. 16. Copchak, O.V., Biloklicska, G.F., Stechenko, L.O., \& Krivosheeva, O.I. (2017). Ultrastrukturna orhanizatsiia tkanyn yasen khvorykh na heneralizovanyi parodontyt pry kardiovaskuliarnii patolohii [Ultrastructural organization of gum tissue in patients with generalized periodontitis with cardiovascular pathology]. Svit 
medytsyny ta biolohii - World of Medicine and Biology, 1 (59), 121-126 [in Ukranian].

17. Sokrut V. N. (1992). Formy reaktivnosti organizma i zazhivlenie infarkta miokarda [Forms of body reactivity and healing of myocardial infarction] Doctor's thesis. Donetsk [in Russian]. 